DOI:10.32703/2415-7422-2020-10-2-185-216

UDC 654.1:654.03

Ángel Calvo

University of Barcelona

696, Diagonal Avenue, Barcelona, Spain

e-mail: angel.calvo@ub.edu

http://orcid.org/0000-0002-1370-9970

\title{
Liberalisation of telecommunications and broadening of the value chain in Southern Europe. Telefónica, 1982-2000
}

Abstract. This article deals with the opening of telecommunications to competition and its determinants in Spain, a country seriously committed to the monopoly. It is framed in the general scenario of an accelerated technological change driven by new materials, components and transmission systems, a sharp regulatory change and an extension of the value chain with new products and services, in particular data, mobile telephony and cable. Such properties fit perfectly with the time axis chosen which comprises the two last decades of the 20th century and coincide with a phase in which the protagonist company is facing the challenge not only of liberalisation but also of a profound change in the parameters of the market. The study focuses on Telefónica's response to new regulatory and market requirements. Methodologically, it revolves around the multidisciplinary nature, which integrates the approach of the history of technology understood as a system (Thomas P. Hugues and Melvin Kranzberg) and the economic and business history (Nathan Rosenberg). The text is structured in four sections that examine the persistence of the monopoly of Telefonica and liberalisation, the axes of Telefónica's transformation through global and strategic plans and the broadening of the value chain, focussed on the cable market. Some preliminary historical and technical issues and key elements in the evolution of the sector are addressed. The text attends to the relations between the market structure inherited from the monopoly and the process, from which the advantages of Telefónica with the rest of the companies emanate. The research rests mainly on primary sources of the company studied, twice as valuable because they are difficult to access by researchers and perfectly determined to grasp the company's strategy, as well as on reports from major international institutions and secondary literature. The conclusion deals with the methodological consideration of the close link between supply and demand-related factors.

Keywords: liberalisation of telecommunications; Telefónica; cable telelevision; value chain 


\section{Introduction.}

In the two last decades of the 20th century, a rapid and profound technological change and a vast movement of deregulation turned the world industry upside down. New materials - optical fibre - the emergence of electronics, satellites and the convergence between telecommunications and computing led to the development of new equipment and the Internet. It came over an extension of the value chain with new products and services, in particular data, mobile telephony and cable.

The operators reacted in a variable way to the opening of markets in-depth to a large extent because they were going through different situations. A review of 356 publications on the internationalisation of telecommunications services revealed a growing body of contributions, covering mainly settlement and regulatory policy, strategic alliances and incumbent reactions to deregulation, as well as in-depth market opening. Fixed-line telephony was the dominant segment in most contributions, while mobile telephony or broadband Internet segments were only included in more recent work (Jakopin, 2008). This is a powerful reason to investigate such a situation in the case study.

We should start with some preliminary historical and technical issues. At the time we focused our research, the cable had already been running for many years. Before that, we considered some key elements in the evolution of the sector.

The cable offers the most efficient vehicle for linking subscribers to a broadcasting centre as well as for connecting individuals belonging to the same network. The cable communication system is the broadband transposition of the telephone signal transport system, a distinctive feature that makes it the most successful technology for receiving, exchanging and processing information (Frèches, 1987).

Coaxial cable television is the classic technology for image and sound transmission. It consists of several pairs of copper wires of varying thickness that carry electrical signals from the network output point to the subscriber. As the Encyclopaedia Britannica points out, commonly known as community antenna television (CATV), these cable systems use a "community antenna" to receive broadcast signals (often from communications satellites), which they then retransmit via cables to homes and establishments in the local area subscribing to the service. Subscribers pay a specified monthly service charge in addition to an initial installation fee.

The original coaxial cable networks were replaced by those using optical fibre, which, being based on light signals instead of electrical signals, has a double advantage: higher capacity and higher speed (Frèches, 1987). Cable began as a rural television service for residents who lacked the over-the-air programming options of urban residents. The supports for this service were microwave radio and satellites. The cable then spread to urban areas because of the diverse programming and as another source of affordability (Wheeler, 1981; Frèches, 1987). Thomas E. Wheeler was the president of the National Cable Television Association. The cable was born in Pennsylvania in the 40s by chance: the difficulties that a television sales franchise holder (Peter Walsonavich) encountered in capturing the television broadcasts 
transmitted by the hertzian route led him to link up by receiving cable to an antenna located on top of one of the surrounding mountains and to provide free cable television service to his customers (Magoun, 2007, p. 116). The pioneer of commercial coaxial cable television would have been Robert J. Tarlton in the late 1940s, along with other residents of Lansford (Mullen, 2008, p. 40). In the US, the cable penetration rate as a percentage of TV households grew from 14\% in 1975 to $24 \%$ in 1980 and $67 \%$ in 2003. In the early days of cable, many aspects of the service were regulated by the authorities, including the terms and conditions of the franchise and subscriber fees. In 1984, the Cable Policy Act imposed some limitations on the regulation of tariffs by the franchise authorities. Eight years later, in response to rising rates, the Consumer Protection Act required the FCC to regulate to ensure reasonable rates for basic service, the lowest level of cable service, which includes local broadcasting (General Accounting Office, 2003, p. 7).

As early as the start of the 1970s, some of the key players - the Sloan Commission - advocated that cable TV should offer "abundance", or greater choice. By abundance, they meant bringing in programmes from other cities and opening up the field of pay$\mathrm{TV}$, as well as choosing between network news and cable news services. Abundance would also mean reserving certain channels for areas of public interest, such as welfare, health, consumer services and public information. The Sloan Commission's (Sloan Commission on Cable Communications, 1971) recommendations included: the diversity of entertainment programme systems - mass and specialised - the variety of channels by purpose - government, quasi-government, educational services and compulsory public access channels. Cable systems should transmit local public broadcasting stations; public television stations should be allowed to operate cable franchises without market restrictions; local franchising authorities should give ownership preference to community institutions; interesting view from the mainstream press (New York Times, December 19, 1971, p. 10).

In Europe, cable TV networks for liberalised services (1994/1995) were used in only one country (UK) and were not used in four countries (Belgium Denmark Germany Portugal). There were variations in France (no voice services), Greece (no cable TV networks), Ireland and Luxembourg (no legal provision), Italy (no cable TV networks, legislation pending), the Netherlands (limited use) and Spain (no but legislation pending) (Eijk, 1995).

European Public Telecommunications Operators or PTOs controlled an increasing share of the cable subscriber market (from $50 \%$ to $59 \%$ ), a trend similar to that of the OECD countries, where the operators share of cable TV subscribers in monopoly Public switched telephone network (PSTN) markets grew from 54 per cent in 1990 to more than 60 per cent in 1994 (Little, 1997, pp. 20-21).

As was the case with most national markets for controlled access and conditional access services, the pay-TV markets were dominated by a small number - one or, at most, three or four main companies - that were highly diversified, largely intertwined, 
strong and operating on an international or regional basis (European Audiovisual Observatory, 2004).

Over the years, the development of the digital television market in general, and of the pay-TV market in particular, has been driven by four main factors. These consisted of an increase in the number of media/market concentrations together with vertical integration of upstream and downstream markets; new bottlenecks and market closures and a change in the way digital products are distributed by bundling content and services into platforms and packages (European Audiovisual Observatory, 2004). Vertical integration refers to the extension of a company's activities through more than one successive stage of the production process or value chain (Little, 1997).

The millennium started with difficulties for the whole industry as the deteriorating economy complicated the transition to digital television, both in terms of rising programme rights costs and the huge investments needed (Lange, 2005, p. 13).

\section{Operating revenue of European Union television companies (1999- 2001) $(000 €)$}

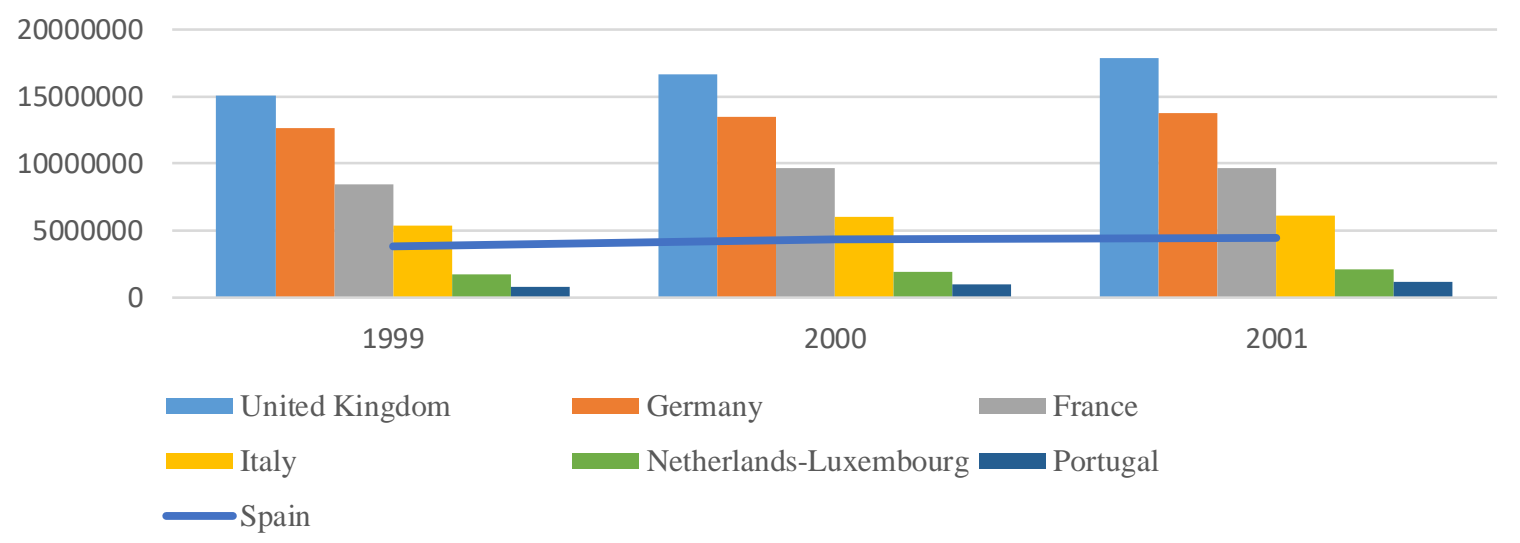

Figure 1. Operating revenue of European Uion television companies (1999-2001) (Lange, 2005, p. 13).

Overall, growth varied from country to country according to a score broadly led by the United Kingdom (16.6 billion in 2000), compared with 13.5 in Germany, 9.3 in France, 5.9 in Italy and 4.3 in Spain (Table 1). In turn, huge disparities among national financial situations existed. In Spain, public enterprises, both state-owned and autonomous community-based, accumulated significant structural deficits. Despite enjoying substantial margins, the two private channels financed by advertising (Telecinco and Antena 3) suffered from the negative impact of competition between the two digital satellite TV platforms (Vía Digital and Canal Satélite) before their merger was enormous (Lange, 2005, p. 8).

\section{Research methods, Results and Discussion.}

Methodologically, the research falls within the scope of a case study, which is granted full validity despite its detractors. It is in keeping with all those who clearly 
distinguish the case study from other research techniques such as the survey in its nature of inquiry of a single instance (Dul \& Hak, 2008, p. 4).

The resaerch revolves around the multidisciplinary nature, which brings together two great historiographic traditions: those represented by Kranzberg, on the one hand, and Rosenberg, on the other. The first approaches the history of technology understood as a system and the second the economic, management and business history.

In his landmark work Networks of Power, Thomas P. Hugues (Hugues, 1983) laid the foundations for the study of technology embodied in large systems - hence the meaning of "large technical systems", LTS - and unveiled the mysteries of what had hitherto been considered a black box. This systemic conception, led by Hughes with a rather sociological approach, was also cultivated by Melvin Kranzberg (Kranzberg, 1986) by equating technological systems with technological packages, so called because they are composed of various components shaped by economic and sociocultural patterns. Nathan Rosenberg (1982) explored it also previously by from the evolutionary economics of technological innovation, which is shaped by science, industry and economics. Unlike Hughes, who focused on electricity networks, Rosenberg studies aspects of innovation in telecommunications (Rosenberg, 1982). Within the LTS stream, ISDN, as an instrument of integration of separate communication networks, was present in the discussion on the generalisation of Hughes' approach to even more advanced stages in the expansion, scaling up or merging of LTS (Mayntz \& Hughes, 1988, p. 15).

By adopting an LTS approach, Nina Wormbs (Wormbs, 1997) traces the development and change in the networks used for radio and television distribution in Sweden from the 1920s to the 1990s. The Swedish broadcasting network is conceived as a socio-technical system composed of both "hard" and "soft" components - purpose built systems, material technology, institutional framework (ownership structure, organisation and standards). In this sense, cable TV is considered a subsystem together with AM, FM, TV, cable and satellite broadcasting systems.

Within the framework of these multidisciplinary approaches, the study contrasts strongly with the dominant literature in Spain, which stands out for its unidisciplinary scope and focuses on regulatory and legal issues - Giordano and Zeller (1999), Montes (2016) and Pérez Martínez and Feijóo González (2000) while less so in the business field (Fernández, 2000). The text is structured in four sections that examine the persistence of the monopoly of Telefonica and liberalisation, the axes of Telefónica's transformation through global and strategic plans and the broadening of the value chain, focussed on the cable market. The research rests mainly on primary sources of the company studied, as well as on reports from major international institutions and secondary literature.

\section{Telefonica: persistence of the monopoly and liberalization.}

Perhaps the most accurate diagnosis of the trajectory of Telefónica de España the new name adopted by the historic Compañía Telefónica Nacional de España in 
1988 - in the last quarter of the 20th century is contained in the speech of its president, Cándido Velázquez Gaztelu, who set out his programme for the transition from monopoly to leadership. At that time, Telefónica had accumulated fundamental transformations experienced in the 1980s with the creation of the circulating holding company and the beginning of international expansion according to different styles, which were difficult to fit into a single model (Table 1) (Statement by Cándido Velázquez Gaztelu at the meeting of the Board of Directors on 20 December 1995, Minutes of the Board of Directors (Libros de Actas del Consejo de Administración, LACA, 20 December 1995). The new structure of the company was defined by the continuity of the decentralization and the management advocated remodeling the organization in only the essential. The results for 1988 showed that Telefónica was perfectly prepared for the investment challenges that the future demanded (LACA, 21 December 1988).

In 2000, Telefónica presented itself as a global company, leader in telecommunications, Internet and media with a strong local presence. It was, in turn, the leading operator in telecommunications, media and Internet in the Spanish/Portuguese speaking world; one of the ten largest telecommunications companies by market capitalisation, the most liquid telecommunications company in Europe and the fifth in the world and one of the global telecommunications companies with the greatest geographical diversification, source of income and value.

Telefonica could boast of a long history of transformation in response to new needs. In 1976, the first stage of regional decentralisation had been completed, which affected Catalonia and was intended to shift the bulk of operational management and the capacity to contribute plans and programmes of action to the company's overall plan to the regions. After twenty-two years, Telefónica adopted new managementand model by services market segment. It included five lines of action, namely Telefónica de España, Telefónica Internacional, Telefónica Móviles, Telefónica Media and Telefónica Intercontinental (Compañía Telefónica Nacional de España, Memoria, 1976, p. 36; Compañía Telefónica Nacional de España, Memoria, 1998, p. 178).

In 1999, by the conversion into an affiliate or subsidiarisation of the basic telecommunications area in Spain, in particular the fixed telephony business, and the transfer of the personal and property assets to Telefónica de España, the essential part of the restructuring process was completed. The Telefónica Group comprised an integrated group of companies which carried out their main activity in the telecommunications, media and entertainment sectors. It was made up of Telefónica, S.A., the parent company, and various subsidiaries and investee companies. The geographical scope of this activity extended to Spain and abroad, while the form in which it was carried out was either directly, in the whole or in part, by the Company, or through companies or other legal entities with an identical or similar corporate purpose. In short, as analysts have pointed out, the model adopted is characterised by a versatility that blends the operational autonomy of the different sectors of activity with horizontal policies (From \& Eliassen, 2007). 
Table 1.The companies of the Telefónica Group, 1985 (Telefónica, Memoria, 1985, pp. 153-154).

\begin{tabular}{|c|c|c|c|c|}
\hline \multicolumn{5}{|l|}{ Direct holdings } \\
\hline & $\begin{array}{l}\text { Share capital } \\
\text { (million pesetas) }\end{array}$ & $\%$ Telefónica & $\begin{array}{c}\text { Telefónica } \\
\text { Results } \\
\text { (million } \\
\text { pesetas) }\end{array}$ & Staff \\
\hline AMPER S. A. & 2400 & 84,375 & 391 & 987 \\
\hline Cables de Comunicaciones & 782 & 49 & 109 & 395 \\
\hline CETESA & 434 & 100 & 61 & 879 \\
\hline COSESA & 700 & 100 & 442 & 385 \\
\hline ELASA & 300 & 100 & 87 & 494 \\
\hline ENTEL S.A. & 350 & 100 & 157 & 718 \\
\hline GRAFIBUR S.A. & 325 & 100 & 6 & 104 \\
\hline H.R.M. & 500 & 100 & 31 & 315 \\
\hline INDELEC & 300 & 30 & 86 & 46 \\
\hline INTELSA & 2600 & 49 & 481 & 2225 \\
\hline SECOINSA & 3125 & 92,875 & 3007 & 1133 \\
\hline Standard Eléctrica & 17604 & 20,99 & 138 & 15127 \\
\hline SINTEL S. A. & 1100 & 100 & 457 & 3121 \\
\hline Telefónica Internacional de España & 200 & 100 & 1 & 3 \\
\hline Telefónica Sistemas & 100 & 100 & 40 & 22 \\
\hline Telettra Española & 2800 & 51 & 125 & 1764 \\
\hline TEMASA & 600 & 100 & 4 & 2 \\
\hline TEPESA & 100 & 56 & 18 & 31 \\
\hline THM & 200 & 73 & 68 & 27 \\
\hline TYD & 225 & 100 & 62 & 120 \\
\hline Urbana Ibérica S. A. & 330 & 100 & 33 & 1 \\
\hline \multicolumn{5}{|l|}{ Indirect holdings } \\
\hline & $\begin{array}{c}\text { Share capital } \\
\text { (million pesetas) }\end{array}$ & $\begin{array}{c}\% \\
\text { Telefónica }\end{array}$ & & \\
\hline CETESA-TELYCO & 50 & 33 & & \\
\hline COSESA-SAPEC & 40 & 35 & & \\
\hline \multicolumn{2}{|l|}{ ENTEL-IBERMÁTICA-SADIELSA } & 266 & & \\
\hline \multicolumn{2}{|l|}{ SINTEL-TECNITEL Co.(Miami) } & $10000 \$$ & & \\
\hline SECOINSA-SADIEL & & 56 & & \\
\hline \multicolumn{2}{|c|}{$\begin{array}{l}\text { Telefónica Internacional de España } \\
\text { Telefonica International }\end{array}$} & \multicolumn{2}{|l|}{$1.750 .00 \mathrm{dm}$} & \\
\hline \multicolumn{2}{|c|}{ Compañía Financiera de Telefonía Española B. V.* } & \multicolumn{2}{|l|}{25.000 florines } & \\
\hline \multicolumn{2}{|c|}{ Telefónica Hispano-Americana* } & $600000 \$$ & & \\
\hline AT\&T Microelectrónica de España & $65 \$$ & 20 & & \\
\hline \multicolumn{5}{|l|}{ In progress } \\
\hline TELCOR S. A. & $6 \$$ & 35 & & \\
\hline CARTOGRAFÍA DIGITAL & 300 & 70 & & \\
\hline
\end{tabular}

* Direct participation of Telefonica International. 
In detail, the main companies in core activities were the following: Telefónica de España (basic telecommunications in Spain), Telefónica Servicios Móviles, S.A. (mobile services, in particular mobile telephony in Spain), Telefónica Internacional S.A. (carrying out and managing investments in the telecommunications sector in the Americas), Telefónica Intercontinental S.A. (carrying out and managing investments in the telecommunications sector outside Spain and the Americas), Telefónica Media S.A. (media and entertainment), Telefónica Data S.A. (integral provision of data transmission services for companies), Terra Networks S.A. (access and services related to the Internet and interactive services in general), Atento Holding S. A. (call centre) and Telefónica Publicidad e Información S. A. (guides) (Telefónica, Memoria consolidada correspondiente a los ejercicios terminados el 31 de diciembre de 1999 and 1998, pp. 90-93).

\section{The pillars of Telefónica's transformation: global planning.}

Following the formulation of the 1983-1986 Four-Year Concerted Plan and its approval by the Government, comprehensive planning took place, culminating in the 1985-1988 Four-Year Plan (Secretaría General de Economía y Planificación, 1985). It aimed to unite everyone's efforts and direct them towards achieving the triple objective of developing services, modernising infrastructures and boosting the industrial sector related to the demand for equipment. As a result, the three-fold service objective involved to "phone" Spain, promote innovation and undertake the management of multipurpose networks. They meant, respectively, developing and extending the basic telephone service, updating the telephone service by incorporating peritelephony services and expanding other telecommunications services (mobile telematics, business communications) and, as a third objective, having an infrastructure suitable for transmitting not only voice but all types of products. These plans inevitably called for a series of management objectives, including the modernisation of infrastructures and their management methods through more integrated and versatile management, with the implementation of technical solutions for advanced operation - call it digitalisation - and internal mechanisation, as well as a more agile and efficient framework of relations with the subscriber.

In the end, the 1985-1988 Plan entailed a management tool of the future to updating services and overcoming possible technological gaps. Its final objective was to reduce diseconomies, to give rise to new procedural formulas and to reach the efficiency levels of the most advanced countries. The Plan thus became an instrument that required very close coordination, a reduction in the time taken to make material resources available and technically qualified, and an organisational development that was permeable to the new management formulas in the dynamic environment of the melting of classical regulation, new social demands and cutting-edge technologies. In its report on the draft LOT to the Government, Telefónica stressed the need to maintain the unity of the network and its management and to liberalise the terminals (LACA, 30 April 1985). 
Telefónica applied severe economic and financial reorganisation measures, which can be summarised in four basic pillars. They spanned from cost containment and an active financial policy, with successive capital increases and debt diversification, to the adaptation of depreciations to the duration of the telephone plant, and the strong trend towards self-financing of investments. Increasing self-financing and repeated capital increases bore fruit, visible in strong repayments, responsible for the improvement of the liability structure, as well as the consolidation of the working capital. The selffinancing/investment ratio rose from 50.9 in 1982 to 66.6 in 1985 (Compañía Telefónica Nacional de España, Memoria 1985, p. 6).

CTNE's foreign currency debt at the beginning of 1984 was PTA 213587 million, of which 34\% was in Swiss francs, $19 \%$ in German marks, 38\% in US dollars, $7 \%$ in pounds and the remaining $2 \%$ in five other currencies. Approximately $80 \%$ of the foreign debt was in the form of international syndicated loans with multi-currency clauses. At the time, the trend towards a reduction in the weight of currencies with a higher expected cost was beginning to emerge. One year later, the participation of foreign capital in the CTNE was between 3.08\% and 8\%. Measures were taken to control foreign investment in CTNE shares (LACA, 30 January and 6 March 1985).

The effervescence to which the country devoted, after the great events of $1992-$ the Olympic Games and the fifth centenary of the arrival in America - affected the whole of the territory. The fruits of the Star Programme for the dissemination of the telephone in rural areas were reaching all its corners. Work began on the Access Network plan, which first totalled PTA 862.8 million, with the capital city taking the lead with $55.6 \%$ and, at a certain distance, the province most directly involved in some of the pomp and circumstance, i.e. Seville in the south with $17.9 \%$. In the second round, the work on the interior and exterior plant was increased by 590.35 and 1669.2 million pesetas (Table 2).

\section{The strategic plans of Telefónica in 1991-1997.}

Given the relatively long time needed to implement new services and to mature the investments required to meet growing demand in quantity, quality and diversity, the five-year Strategic Plan has been consolidated as our fundamental instrument for planning the Company in the medium and long term.

Maintaining its basic lines in terms of strategic objectives, priorities and policies, the forecasts and specific objectives have been outlined, incorporating the modifications that have been considered appropriate according to the evolution of the market situation for telecommunications services. The Strategic Plan is updated every year, always maintaining a five-year time horizon.

The priority objective of the Plan, and consequently of the programmes derived from it, continued to be the improvement of quality. In fact, in the 1991-1995 Plan, the main quality objectives were brought forward by one year, to achieve in 1992 levels that were perfectly comparable with the most advanced countries, although in 1991 these objectives will already be achieved in most provinces. The objectives of reducing 
the waiting list were also brought forward in time, so as to reduce it to a purely residual level as soon as possible.

Table 2. Access network programme. Work on the internal and outdoor plant which was expected to be accepted or available in 1992-1993 (million pesetas)

(LACA, 25 July 1992; LACA, 26 May 1993).

\begin{tabular}{|l|c|c|c|}
\hline \multirow{4}{*}{ Provinces } & $\begin{array}{c}\text { Investment } \\
\mathbf{1 9 9 2}\end{array}$ & $\begin{array}{c}\text { Investment } \\
\mathbf{1 9 9 3}\end{array}$ & $\begin{array}{c}\text { Total } \\
\text { investment }\end{array}$ \\
\cline { 2 - 4 } & \multicolumn{3}{|c|}{ million pesetas } \\
\hline Málaga & 25.20 & - & 140.20 \\
\hline Granada & 18.50 & - & 100.1 \\
\hline Almería & - & 39.6 & 237.9 \\
\hline \multicolumn{4}{|c|}{ East coast } \\
\hline Valencia & 61.80 & - & 309.8 \\
\hline Castellón & - & 38.9 & 194.3 \\
\hline \multicolumn{4}{|c|}{ Centre } \\
\hline Madrid & - & 35.7 & 162.3 \\
\hline Cuenca & 3.05 & - & 15.25 \\
\hline La Rioja & 9.10 & - & 45.8 \\
\hline \multicolumn{5}{|c|}{ Basque Country } \\
\hline Vizcaya & - & 160.9 & 804.8 \\
\hline \multicolumn{5}{|c|}{ Catalonia } \\
\hline Gerona & - & 30.2 & 141.6 \\
\hline \multicolumn{5}{|c|}{ Canary Islands } \\
\hline Las Palmas & - & 21.2 & 398.3 \\
\hline Tenerife & - & - & 538.1 \\
\hline \multicolumn{5}{|c|}{ Aragon } \\
\hline Zaragoza & - & - & 22.3 \\
\hline Total & 117.95 & 326.5 & 2.475 .1 \\
\hline \multicolumn{5}{|c|}{ Outdoor plant projects in 1993 } \\
\hline Barcelona & - & - & 61.4 \\
\hline Córdoba & - & - & 22.4 \\
\hline La Coruña & - & - & 7.8 \\
\hline Jaén & - & - & 16.1 \\
\hline Sevilla & - & - & 29.7 \\
\hline Reserva & - & - & 273.7 \\
\hline Total & - & - \\
\hline \multicolumn{5}{|c|}{} \\
\hline
\end{tabular}

With a clear awareness of the demands posed by the liberalisation of telecommunications and the establishment of a new competitive framework, corporate 
organisation was strengthened. The position of CEO (formerly Managing Director), who had a long tradition in the company, was re-established, and the financial area would continue to depend directly on him. The areas of Economic Analysis and Studies, Strategic Planning, Subsidiaries and Participated Companies, and Communication and Corporate Relations were brought together in a General Directorate of Corporate Planning. A General Resources Department was also created, grouping together the areas of Human Resources, Intervention and Accounting and Information Systems (Telefónica, Memoria 1990, pp. 10-11).

The incorporation of Spain into the European Community imposed a supranational regulation, based on the separation of the regulatory functions, reserved to the State, and the operational functions, assumed by the operators. The inclusion of this guideline in the 1987 Telecommunications Law called for new bases for the relationship between the State and Telefónica. A new concession contract, replacing the one signed in 1946, returned all the sector's regulatory functions to the government and defined a new framework for the company's activity. Telefónica maintained its monopoly of the basic telephone service, although now subject, as is the case with Spanish legislation, to the guidelines of the EC (Telefónica, Memoria 1991, p. 4). Years before, the EEC's advisers had considered three options for restricting the provision of cable TV: maintaining the status quo; lifting restrictions on certain PTOs and/or giving dominant PTOs rights to provide cable TV capacity over telecommunications infrastructure.

The breadth and depth of the changes brought to light the profound business transformation in which Telefónica was immersed to achieve a strategic positioning in the face of the new regulatory, economic and social conditions in which our business activity is carried out.

Telefónica focused on maintaining its leadership capacity in the national market and on contributing to the development of Spanish and European society in a highly competitive environment. The first condition was to be identified by its current and potential customers as the preferred vendor of telecommunications services in a market that is increasingly open to competition. The already initiated selective strategy of objectives and management formulas maintained the same end, based on the double formula of continuous quality improvement and lower production costs, together with an active marketing policy adapted to each line of business in search of a segmented demand.

The new slogan was therefore called competitiveness or submission to the test of validation of its economic efficiency by the market. Indeed, Telefónica already saw a framework of full competition in place with the definition of deadlines for the granting of new mobile phone licences and the entry of new operators in market segments such as business services, terminals and international communications. Active marketing slogan: "selective and segmented offer: to each market segment the precise solutions it requires" (LACA, 12 June 1992). 
These objectives had unavoidable organisational consequences. The next step was the announcement of an organic and functional restructuring to encourage businesses that were opening up to the competition by giving them greater administrative autonomy, streamlining management and improving efficiency. The new General Directorate of Business Communications, the strengthening of TS1, Telefónica Servicios S.A. as a leader in mobile services, the reinforcement of the coordination of commercial activities and the exploitation of existing synergies between various services were all aimed at this direction (LACA, 25 November 1992).

Then it fell to Telefónica Sistemas (TS), which the parent company wanted to be more closely linked to it. Telefónica Sistemas became an instrument to consolidate and strengthen Telefónica's offer in the business communications market. The way forward consisted in bringing together around this subsidiary a new group of companies with the capacity to respond to the growing and complex demands of business customers. In its first steps, the plan would start with two TS subsidiaries of different characteristics and scope. One would cover the engineering field to offer satellite communications to businesses and commercial television, among other purposes; the second would have the task of providing advanced information and intercommunication services. The list of advanced services included e-mail, data, card management and database access (LACA, 4 February 1993).

The reorganisation was accompanied by a two-pronged strategic plan for the years 1993-1997, the first in the context of the advanced convergence plan and the second in the field of information systems. This five-year plan aimed, among other things, to improve the financial results with a better balance between the different businesses, to achieve a corporate image in the eyes of the customer as a competitive, responsible, solid and agile seller, and to provide quality services at a reasonable price. If we want to be strict, both plans included and extended a 1990-1994 Plan, whose most significant variation was in a better adjustment of investments and in the reduction of waiting lists, and the subsequent 1991-1995 Strategic Plan, which was tentative and somewhat voluntarist, and which contributed the novelty of prioritising the stimulation of traffic, public telephony, especially that owned by others, and the allocation of resources with a view to productivity, while seeking to improve the rate of revision of investments and the operating margin (LACA, 28 November 1990).

In the core business, Telefónica's task was to establish definition criteria and ensure profitability and offer tailor-made products and services for large customers with the application of several policy categories. To begin with, it was necessary to identify the large customers and the most important multinational companies in search of strategic revenue sources. In a further step, attention had to be paid to vertical industry sectors, such as banking, airlines and distribution companies, among others. It was also necessary to establish a specific approach for all activities that would subsequently be coordinated (one structure, not project management). Not least, it was necessary to rely on the cross-functional matrix to use change and mobility to overcome corporate inertia. Closing the list of policies was the requirement to select 
preferred contractors to help correct Telefónica's weaknesses and to broaden horizons towards software activities.

In this strategy, internationalisation occupied a prominent position within a more general plan, always understood as a presence in other markets and as an international operator ready to forge global alliances. This close link between internationalisation as a part of a strategic plan goes far beyond its simple inclusion in a list of objectives or plans and, in our opinion, has not generally received sufficient attention. Calvo (2016) has devoted an extensive analysis to internationalisation.

The plan, which estimated a $31 \%$ increase in net line demand, provided for uneven growth in the different service segments, with greater intensity in mobile telephony, which would be multiplied by 3.55 compared to 1.13 in basic telephony lines and 1.74 in the Ibercom-ISDN network. Estimates indicated that the Ibercom-ISDN network would increase 1.74 times in 1997 from 571000 in 1993 and mobile telephony would more than triple from 325000 (LACA, 27 January 1993). The communication standard Integrated Services Digital Network (ISDN) was called in Spain RDSI (Red Digital de Servicios Integrados).

The second major issue was the Strategic Plan for Information Systems, this time of a four-year nature (1993-1996), in response to the inadequacy of the plans in force to support Telefónica's corporate and operational strategy in the face of the challenges posed in a competitive environment. The strategic objectives of the Plan were the introduction of new services, improvement in quality, customer service, consolidation of business areas, cost reduction and security of the systems themselves, all aimed at making the information systems support Telefónica's strategies and operations. As a logical consequence, it was necessary to stop investing in old systems and to define a new strategy for the Information Systems divided into fundamental areas. Two of them - those of the commercial and network areas - were already defined and structured, while the third - resources - was in a preliminary phase. In the Commercial area, the new billing system was noteworthy, which aimed at the automatic collection of consumption and detailed, staggered billing by client, together with a large client module, supported by databases, designed with advanced software engineering and planned to obtain short-term results. In the area of network information, the objective was an integrated planning system, completing the operating systems, automatic management and connections with the commercial system. The choice of international standards, in short, would allow the maximization of the return on investment and the automation of the operation and management of the network. In the definition of the priorities, the planning, management and control of investments; operation and maintenance structure; circuit management (ATLAS); automatic flow management (traffic); geographical information systems and plant maintenance systems were all considered. The Resources area aimed to complete computerisation, simplify administrative processes, integrate with network and commercial systems, coordinate strategies and platforms of the Telefónica group and improve decision-making and management control processes. Here the most important projects were purchases and 
warehouses, human resources, management information, costs, budget control and commitment to third parties. By one estimate, the 1993-1997 Information Plan would increase sales of additional services, shorten installation and breakdown repair times, improve the profitability of investments, reduce financial expenditure and contain staff and personnel costs (LACA, 27 January 1993).

Telefónica encouraged a strategy in the definition of the corporate identity and global image to respond to the challenge of liberalisation, internationalisation, globalisation, new competitive scenario, expansion of the offer of new products and services. The objective was to maintain the leadership in the Spanish telecommunications market and to reinforce the commercial and service attitude. In substance, it sought to reinforce the character of a private company, to superimpose on the image of voice telephony that of advanced and diversified technology and, finally, to preserve the real value of roots and service to the country historically led by Telefónica in telecommunications. He recommended an evolution without radical change because "Telefónica is a renewal in continuity"; "we cannot draw a blank canvas of the unquestionable historical role that Telefónica has played in the technical progress of Spain". The modification of Telefónica's corporate symbols was approved (LACA, 4 February 1993).

It is now necessary to break away for a while from the chronological account to bring in an element of great scope, namely the concerted action between the company and the state in the extension of the telephone service to suburbs and rural areas.

The action specifically dates back to the dawn of the democratic era. In 1978, a government order on this sector of demand for telephone service sought to combine criteria of strict economic profitability with arguments of a political-social nature to extend telephone service to the whole nation. A 1981 decree, accompanied by the usual regulations, established a plan to install public telephones in municipalities without telephone service with a population of 50 or more inhabitants. Its development involved the public administrations, state or otherwise, and the Spanish National Telephone Company (State public administrations, provincial councils and island councils). A step forward was taken three years later, when the collaboration of the territorial entities that made up the Nation-State (Autonomous Communities) and of individuals was definitively promoted in the extension of the service, with special emphasis on collaboration with Telefónica, which became a lever and the main stimulus for regulated actions with their calendar. The acute awareness of the problems of the telephone service was materialised in a constant presence in the annual budgets of a large part of the autonomous entities. For its part, Telefónica signed agreements for the extension of the telephone service between 1986 and 1991 with territorial bodies and individuals. The 1988-1991 Government Plan included a large number of objectives - 8443 new urban areas, 5700 public service telephones and a waiting list of some 44000 requests from the suburbs. Due to their geographical dispersion, the average costs were high and the resources insufficient. In any case, the 1991 plan to extend the service to rural areas brought the public telephone to towns with 50 or more 
inhabitants and the urban service to all towns with more than 100 inhabitants. Telephone service extension agreements signed between 1986 and 1991 with local authorities and individuals respectively: 15 and 14 in 1986; 96 and 306 in 1987; 62 and 473 in 1988; 84 and 334 in 1989; 85 and 328 in 1990 and 84 and 689 in 1991 (Telefónica, Memoria 1991, p. 6).

At the end of the first quarter of 1993, the Government approved the Operational Plan for the Extension of the Rural Telephone Service 1993-1996 (Table 3). As an example of its objective of universalising telephone service, it involved the installation of 427364 telephone lines and 13790 public telephones using TMA cellular access technology. In another aspect of its scope, it required an investment of ptas. 103.100 million, three quarters of which was borne by Telefónica and the rest by the local authorities. The aim was to universalize the service so that all citizens living in rural areas could have telephone service at the same prices and within the same time frame as citizens living in urban areas (LACA, 28 April 1993; BOE, 12 May 1993, pp. 14088-14100).

Table 3. Operational Plan for the Extension of the Rural Telephone Service 1993-1996 (BOE 12 May 1993, pp. 14088-14100).

\begin{tabular}{|l|c|c|c|c|c|}
\hline & \multicolumn{5}{|c|}{ Investments needed (millions of current pesetas) } \\
\hline & $\mathbf{1 9 9 3}$ & $\mathbf{1 9 9 4}$ & $\mathbf{1 9 9 5}$ & $\mathbf{1 9 9 6}$ & Total \\
\hline $\begin{array}{l}\text { Subscription } \\
\text { lines }\end{array}$ & 24.500 & 24.200 & 25.600 & 25.700 & 100.000 \\
\hline P.S. T.* & 1.200 & 1.600 & 200 & 100 & 3.100 \\
\hline Total & 25.700 & 25.800 & 25.800 & 25.800 & 103.100 \\
\hline \multicolumn{5}{|c|}{ Financing } \\
\hline Telefónica & 19.275 & 19.350 & 19.350 & 19.350 & 77.325 \\
\hline Outside & 6.425 & 6.450 & 6.450 & 6.450 & 25.775 \\
\hline Total & 25.700 & 25.800 & 25.800 & 25.800 & 103.100 \\
\hline
\end{tabular}

* P. S. T. - public service telephone.

The 1993 Annual Employment Plan aimed to bring the level of employment in line with the needs of the Strategic Plan, with a ceiling of 74100 employees and to increase line productivity per employee by 3.2\% (LACA, 24 March 1993).

An important element were the new telephone tariffs, which received differentiated treatment according to categories. The average increase of $2.1 \%$ was $5.3 \%$ for metropolitan calls and $4 \%$ for long-distance calls. Intercommunity calls, mobile calls and telematics tariffs benefited from reductions of $2 \%, 12.6 \%$ and $4 \%$ respectively (LACA, 28 April 1993).

It seems clear that one of the mainstays of Telefónica's transformations was the liberalisation of telecommunications promoted by the government on the initiative of the EEC, which had already been largely achieved, and to which the operator was favourable, under the decisions of the Spanish government (LACA, 24 July 1996). In 
response to Airtel's complaint, Telefónica stated that it was unaware of the problems raised by the granting of the second mobile telephony operator's concession (Retevision).

As a result of organisational restructuring in 1994, Telefónica was configured as a corporate nucleus and eight business areas. It then transferred the business to specific subsidiaries, with the consequent assignment of assets and management systems. To do so, it had to obtain the approval of the General Secretariat of Communications, the national regulatory body attached to the administration. The reorganisation had a threefold objective, starting with that of meeting the challenges arising from the liberalisation of telecommunications, which was reflected in the complete opening up of the voice and infrastructures services market. It was followed by ensuring that the managers of the various businesses took full responsibility for the results. Finally, a Group management committee would ensure an overall view of all the businesses. The reorganisation was extended the following year with another partial one as it exclusively affected the international communications management as a preliminary step to the creation of an independent company (LACA, 22 February 1995; Telefónica, Memoria, 1994, pp. 32-35; Telefónica, Memoria, 1995, p. 8). Telefónica decided to adjust its territorial organization to that of the Spanish state in autonomous communities and to carry it out gradually. In addition to the already constituted territories - Galicia, Extremadura and the Canary Islands - five new territorial units were proposed - Aragon, Castile-La Mancha, the Basque Country, Andalusia and Castile-Leon (LACA, 31 January 1996).

The novelty of the 1996 reorganisation consisted of identifying customers and segmenting markets to differentiate up to five business units - General Public, Companies, Telefónica Móviles, Telefónica International and International - capable of meeting consumers' needs on time. The units enjoyed full organisational autonomy in such fundamental matters as product design, prices and advertising campaigns. The Corporate Centre, and more specifically the Management Committee, which was responsible for submitting proposals to the Executive Committee and the Board of Directors, was responsible for coordinating all areas. Prominent businessmen and jurists joined the Board of Directors (Merger Court Report, 1996, p. 13). Content and tone of the measures strongly resembled what had already happened to Ericsson. In a comparative view, after more than a century devoted almost exclusively to telecommunications, especially in plant equipment, Ericsson undertook a restructuring and expansion of its product range, with a pronounced market orientation (Svedberg, 1981, p. 150).

Despite recent restructuring, the new landscape of the liberalisation process and opening up to competition and legal requirements, resulting from legislative decisions or the principle of neutrality in network management, called for further major organisational changes. The reason for the intensification of restructuring, more explicitly related to financial restructuring, in certain periods, was discussed Donaldson (Donaldson, 1994). 
Telefónica aspired to encompass in its strategic plans not only the need to improve quality, brand image and infrastructure, but also the new demands arising from the changing environment. In this sense, it needed to identify its activities to individualise and break down the different businesses it managed, while also separating the services that covered common management needs, the so-called areas or corporate services. To express this in terms used at the time, the aim was to prioritise the autonomous management of these businesses, counteracting the centrifugal force of this autonomous management with the centripetal nature of the existence and operation of the corporate areas. Decentralisation, autonomy and efficiency formed the links in the chain (Telefónica, Memoria 1994, p. 10). Experts argue that decentralisation brings in a centrifugal force, requiring management to impose a centripetal force in the form of policies if it expects to maintain control over decentralised units (Adizes, 2004, p. 66).

The change implied a clear separation between the responsibilities of the corporate areas and those of the management of the businesses themselves, which were divided between Telefónica and independent companies. As a result, subsidiaries were assigned to either the corporate core or the business areas, depending on the nature of their function.

The identification of businesses, one of the stepping stones in the planning of a portfolio strategy, revealed the existence of eight units, including three in telephony basic, integrated by infrastructure and commercial areas; mobile and public use; international communications, data transmission; international business; information and advertising; and multimedia services. Of these, only basic telephony and international communications remained within the scope of Telefónica de España, while the remaining areas became independent companies.

In the new design, the corporate nucleus had the task of coordinating the strategy of the group of companies and guaranteeing its balanced growth and development, the appropriate management of financial resources and the optimum use of human resources. It would consist of a general secretariat, coordination, planning, administration and resources and finance and management control (LACA, 30 November 1994). The planning of a portfolio strategy also includes the evaluation of the existing distribution of the company's business units, identification of the desired future balance of the portfolio and implementation (Leontiades, 1987, p. 40).

In truth, the reorganisation pursued a combination of the versatility and flexibility of the autonomy of its business units with horizontal policies, an organisational philosophy of activities by lines applied by European operators years later by the Belgacom Group in 200 (From \& Eliassen, 2007); business units: Hollensen (Hollensen, 2012).These acknowledged that the business unit, and not the divisional or corporate level, is the appropriate one for the construction of a value chain, which is why it can be described as a competitive strategy. According to Chandler's vision, there appear to be clear symptoms of the transition from a multi-functional multi-unit company to a multi-divisional company that separated the strategy from operation and, consequently, from centralisation and division by function to division by product 
characteristic (Chandler, 1990). It seems appropriate to point out that some specialists describe internationalisation as an alternative to the diversification strategy and the multi-divisional structure (Binda, 2013, p. 162). The debate between universalists - a single economic and managerial organisation - and institutionalists - national differences - remains polarised. In 1993, even French and German firms were at or near the level of three-quarters of the divisionalization reached by American firms in 1969. A slow but clear advance of the continental countries towards the Anglo-Saxon organisational model together with the universal collapse of the centralised functional organisation appear as the main characteristics (Whittington \& Mayer, 2000, p. 37).

It should not escape the observation that Telefónica's transformation from a telephone operator into a communications company, providing services to a wide range of customers, ran parallel to its expansion (Kalotay, 2004).

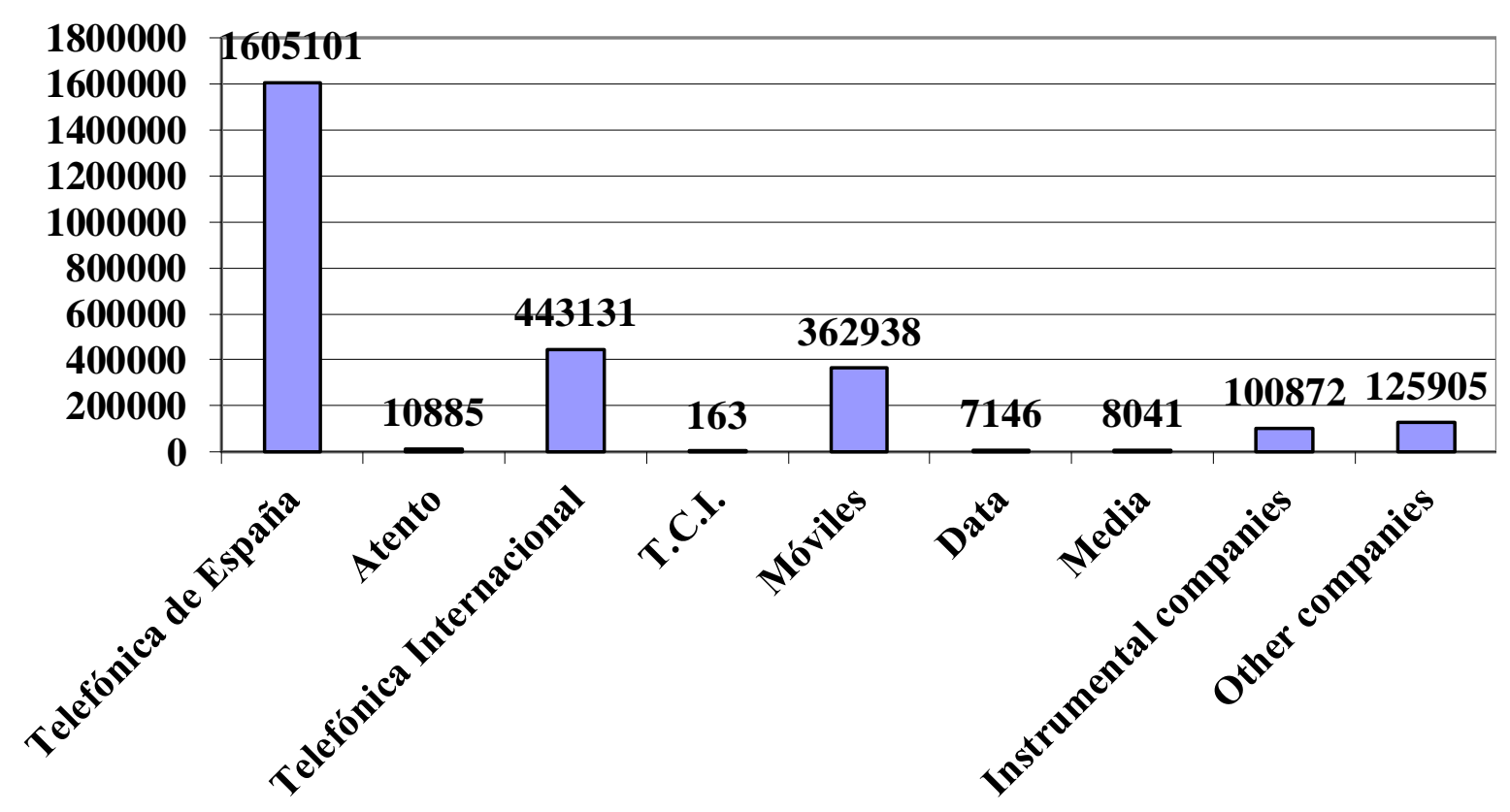

Figure 2. Income structure of Telefónica by operations by 1999 (million ptas.) (Based on Telefónica, Memoria, 1999, p. 200)

The reorganisation culminated in the Operation Veronica, which led to the Group being organised into business lines that are now global in scope, with a vocation for world leadership within each area of activity. In 1995, the operator closed the first phase of Operation Veronica, by which - following the successful completion of its takeover bids for Telefónica de Argentina and the Brazilian companies Telesp and Telesudeste Celular - it gained control of $96 \%, 87.5 \%$ and $89.3 \%$ respectively of these companies. At the dawn of the new century, this operation would culminate in the consolidation and strengthening of Telefónica's presence in Latin America, substantially in the markets already conquered (Calvo, 2016). 
In the new structure, the ordering of assets by business replaced the previously prevailing criterion, i.e. by country. Three business units opened in 1998 - Terra, Telefónica Publicidad e Información (TPI) and Telefónica Media - and were joined the following year by two more - Telefónica Móviles and Telefónica Datacorp - and, successively, by four new ones - Atento, Katalyx (Business to Business), Telefónica Internacional and Emergia (underwater fibre optics). The Telefónica Group was thus shaped as an integrated group of telecommunications, media and leisure companies headed by the parent company Telefónica, S.A. This reinforced the corporate strategy aimed at optimising the synergies of the coordinated action of the different areas. This had allowed the successful implementation of shared policies through the advanced purchasing system, cost optimisation systems -Shared Services Centres-, coordinated information systems strategies, the first global human resources actions carried out with the TIES plan, as well as the coordination and development of actions in the field of institutional relations (Telefónica, Memoria, 1999, pp. 11-12). The new organisational structure tried to meet the Group's objectives, in particular an increase in the value of the business and its return to shareholders. Five priorities were established: development of the organisational model of an integrated telecommunications group, the transformation of the telecommunications business in Spain, undisputed consolidation as a leader in the mobile phone business and optimisation of the portfolio of other subsidiaries. This was a new customer-oriented organization based on management by business units with three basic pieces. The Corporate Centre's mission was to guarantee the strategic orientation of the Group, which comprised the areas of Management Planning and Control, Institutional Relations, Corporate Finance, Regulation and the General Secretariat of the Board; five business units - Companies, General Public, TISA, Mobiles and International-, focused on markets, customers and products and with objectives based on profit and loss accounts; two shared resource units - Infrastructure and Businesses-, to support the business units and to provide common services. Moreover, four committees were set up: a management committee, with an executive role and an instrument for defining policies and resolving key issues relating to the whole Group; a financial committee, for risk management and balance sheet; a basic telephony committee and a resources committee. At one point in the reorganisation, Telefónica Latinoamericana was the business line responsible for fixed telephony assets in the area. The sums managed and saved in one year within the advanced purchasing system, which began in 1998, exceeded 1.5 billion and 200,000 million pesetas respectively (Telefónica, Memoria, 1999, p. 58).

In 1996, Telefónica noted a list of positive and negative factors arising from its competitive position. Among the former, the improvement in quality to the level of that of competitors, the maintenance of productivity levels and the achievement of leadership in operating margins, the favourable evolution of profitability on own resources, the firm international positioning due to its establishment in Latin America and incorporation into Unisource, together with the spectacular improvement in public 
opinion, stood out. The list of negatives included the risk associated with tariff imbalances, the low perception of the quality-price ratio, the relatively low generation of income from new services in comparison with other advanced operators and the imbalance in profitability both by business areas and by services in basic telephony (LACA, 20 December 1995; the strategic plan 1996-2000 was studied during several meetings in the central emblematic of Buitrago: LACA, 29 November 1995). The quality of the service improved between 1990 and 1997. In response to increased competition, Telefónica reduced concession times for international leased lines to an average of 44.7 days; fault reports per 100 lines fell from 9.87 to 8.48 per month (OECD, 2000, p. 297).

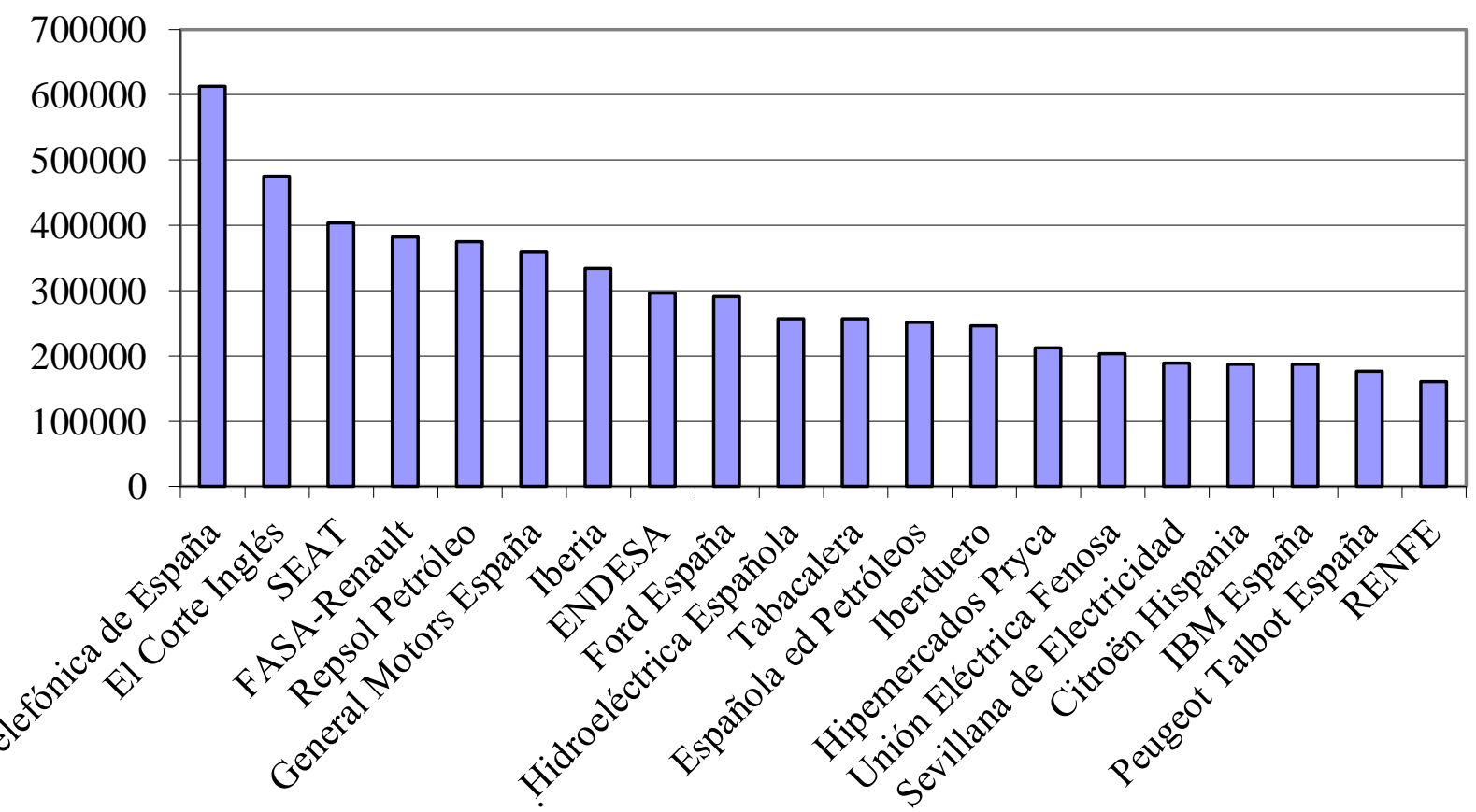

Figure 3. The 20 largest non-financial companies in Spain, 1998 (million ptas.) (Binda, 2013, p. 249)

With the 1996-2000 Strategic Plan, in a context of change in the country's political orientation with the arrival of the right-wing government, it sought to maximise the value of the company for the shareholder by conquering leadership in a context of growing liberalisation of the sector. Achieving this required improving efficiency in the operation of traditional businesses, paying special attention to highgrowth and emerging businesses, without neglecting improvements in costs, economic profitability and financial (LACA, 20 December 1995).

\section{Broadening the value chain: the cable market in Spain and Telefónica.}

So far, we have provided an overview of the structuring of an operator in a context of telecommunications liberalisation. We now turn to one of the aspects: the 
Telefónica's responses to the extension of the value chain by a new product - cable -, one of the aims of the article.

If we go back to the beginning, in Spain, Law 42 1995, of 22 December, on cable telecommunications authorised cable operators to provide services in a specific sector of telecommunications, those provided through cable networks. These included sound broadcasting services and image transmission services of an interactive nature, the latter being the main core of the service as it was considered to be the fastest-growing. Cable telecommunications were a state-owned public service by the general principle enshrined in the Telecommunications Law itself. The cable telecommunications service was to be provided by territorial demarcations of variable scope - municipal district, the grouping of various municipal districts - and was to be achieved by public tender. The awarding of the contract empowered the concessionaire to provide this service and to establish the network for this purpose, for the provision of other telecommunications services and even as a carrier service for services provided by third parties. The company was authorised, by a series of requirements and conditions, to provide these services in all areas, which are inseparable from the basic telephone service. The law, therefore, combined respect for the privileged position enjoyed by Telefónica de España under the contract with the State with the existence of the necessary competence in the provision of these services. The Law limited the number of cable operators in each territorial district to one, in addition to Telefónica de España, SA. This restriction was motivated by economic considerations, since the operation would not be viable in the event of a proliferation of operators, given the high amount of investment to be made. In the development of this service, the establishment of formulas for cooperation between industrial companies, research centres and service operators was to be encouraged to ensure the best use of the technology available (BOE, 306, 23 December 1995, pp. 36790-36796). See for details of the complex elaboration of the Law the Minister of Public Works and Transport Response to Socialist Deputy Ms Anna Balletbó (Journal of Sessions, Congress of Deputies, Commissions, 13 MAY 1992, 187, p. 9,201). In 1996 a Memorandum of Understanding was reached on Telefónica's contract with the State: LACA, 30 October 1996. Political debates on the Cable Law (Montes, 2016).

In the Spanish cable industry, three elements of activity coexisted, namely the disparate nature, the complementary nature and the presence of obstacles to internalisation. The first can be explained by the absence of all the skills of a company to carry out its activity. It applies to the nascent cable industry in Spain because this industry involved a multiplicity of activities, each of which had to function perfectly. After all, this systemic nature meant that the goodness of the service offered depended on all the links in the value chain. The same applies to the second, which is a nuance of the previous one. Finally, the third is entirely applicable to Spain because the main obstacle is financial, resulting from the significant investment required for this activity.

A close connection exists between the development of cable companies and the liberalisation of telecommunications. The operators who entered the fixed telephony 
market as a result of the liberalisation of the sector by breaking up the monopoly Retevisión - and the duopoly - Lince Telecomunicaciones - participated directly in the capital of the cable operators or through shareholding partners in both (Fernández, 2000, pp. 177-186).

The group of companies set up to operate in cable television was originally made up of 14 consortia established on a territorial or more general basis. The list included Cableuropa, Cablevisión, Cable TV Europa, three Andalusian entities (Sevillana de Cable, Cable del Guadalquivir and Jerez de Cable), Telecable (Asturias), Santander de Cable, Telecable Compostela, Burgos Sistema de Cable, Grupo Cable, Operadora Cable Sistema, Zaragoza de Cable and Marbella Cablevisión. They were made up of twelve financial institutions (BCH, BBV, Banco de Santander, Banesto, Banco Pastor, Caja Círculo Católico, Caja Cataluña, Caja de Pontevedra, Caja de Vigo, Caja de Orense, Caja Galicia and Caja Cantabria), four energy companies (Iberdrola, Sevillana de Electricidad, Unión Fenosa and Electra del Viesgo), media and infrastructure companies, local authorities and other service companies (Annexe 1). In terms of size, the cable market in Spain was made up of three strategic groups of cable operators: modest, intermediate and large operators. The characteristics of this last group include a majority of financial partners and a small presence of foreign companies (Miguel \& Fernández Peña, 1998).

They have been setting their targets on Spain since at least 1994. It is interesting to follow in the footsteps of some of them. In order to focus on the most significant one, US West did not hide its intentions to invest in Spain in an interactive communication network with the new cable TV law. The changes introduced by the PP government in the cable legislation coincided with the aspirations of US West in its Spanish landing. It was the first of the regional companies resulting from the break-up of the US multinational giant AT\&T to diversify into cable television on a large scale through its $25.5 \%$ investment in Time Warner Entertainment (a joint venture with Time Warner, Toshiba and ITOCHU) (Spain and Talbot, 1995, p. 888).

In the plans, US West's main partners in Cable i Televisió de Cataluña (CTC) Banco Santander and ENDESA - were to form the nucleus of Retevisión when it was privatised. US West and its partners were to bid for all tenders in Spain. Initially, if US West, through CTC, won the three Catalan regions, as it expected, it would be involved in a global investment of Ptas 130 billion. In exchange, it would bring the cable to 2.5 million homes, a very interesting critical mass, which would allow us to offer many specific services and contents, in the expression of a high directive of the North American US West in Spain - Maureen O'Ryan. She believed that the imminent appearance of digital television did not mean that cable had become obsolete. Through Cable i Televisió de Catalunya (CTC), this company initially cabled 20000 homes in Barcelona and was the technological partner of Euskaltel, which would act as the second largest Telefónica in the Basque Country. On the shape of telecommunications in Catalonia (Martí-Recoder, 1991). 
Over time, the number grew as requests for public service provision were extended to new territorial districts. In Madrid, two more consortia soon emerged: Madrid Sistemas de Cable (France Télécom, Bank of America, Banco de Santander and $\mathrm{BCH}$, among others), which submitted bids to the three regions into which the cable tender was divided, and CYC Telecomunicaciones Madrid, a consortium made up of six large business groups in the three regions (Unión Fenosa, Endesa, the Zeta Group and Telecom Italia, among others). CYC won the contract for the three districts and its projects included providing the cable service to 700000 Madrid residents in September, offering a telephone service and some television channels to at least 150000 households from October, and cabling the entire region in six years. In order to lay the cable, the company wanted to make an agreement with the Canal on the use of its pipes, with the City Council on the use of its underground galleries and traffic lights, and with the electricity companies on the use of their conduits (El País, 14 February 1998, 6 and 12 March 1998). The two large business consortia - Madrid Sistemas de Cable and CYC Telecomunicaciones Madrid - which competed for the cable network in Madrid submitted bids to operate and were severely disqualified. Cableuropa, one of the shareholders of Madrid Sistemas de Cable, accused its opponent CYC Telecomunicaciones Madrid of inflating its investment proposal. In the meantime, he said that if his group lost the tender, the duopoly of Telefónica and Retevisión would be consolidated and tariffs would not fall (El País, 23 January 1998).

Supercable Andalucía, which included up to eight electrical, financial and audiovisual companies, won the contract to provide the public cable telecommunications service in the territorial demarcation of Andalucía III.

Sevillana de Cable, Get-Grupo Eléctrico de Telecomunicaciones, Montes de Piedad y Caja de Ahorros de Ronda, Cádiz, Almería, Málaga and Antequera UNICAJA-; Caja San Fernando; Monte de Piedad y Caja de Ahorros de Huelva y Sevilla; Procono y Supercanal de Cable de España (BOE, 79, 2 April 1998, p. 11.281). The new ones also included Huelva de Cable y Televisión.

The cable started to develop more slowly than expected in the different districts. Business circles attributed the delay above all to bureaucratic problems - building permits from the local authorities - and supply problems - the arrival of new competitors not originally foreseen. It seemed possible that they would be granted some kind of moratorium on the deployment of their network in areas of lower density or that they would be awarded a licence to provide their services by radio access, at a lower implementation cost (Pérez Martínez \& Feijóo González, 2000, p. 226). Various initiatives for cabling in Spanish cities took place in a context of very intense liberalisation, but in the absence of regulation, and of technological development in telecommunications, together with a position taken by the Constitutional Court (Journal of Sessions, Congress of Deputies, Commissions, 558, 20 September 1995, p. 16.974).

The deployment of cable networks by region was concentrated strongly in Andalusia, with more than half. This autonomous community had transferred its radio 
and television services, which it had managed since 1987 through the Empresa Pública de la Radio y Televisión de Andalucía as a public law entity (BOE, 14-16 January 1988, pp. 1593-1597). The provinces with the most cable networks were Seville (72), Córdoba, Huelva (34), Granada (33), Alicante, Jaén and Malaga (28) and Cádiz (24); outside Andalusia, Murcia (54) and Alicante (28) stood out.

A key element in Telefónica's aspirations to become the fifth largest operator in the world lay in its participation in audiovisual businesses (Telefónica, Memoria 1997, p. 8). Shortly after the beginning of the 1990s, still under the chairmanship of Cándido Velázquez Gaztelu, Telefónica set out to take up positions in the television segment. With this in mind, it drew up plans for the organisation and operation of businesses related to cable television systems, project development and the provision of audiovisual and interactive multimedia services.

Telefónica endeavoured to gain an advantage in the cable TV market before the market was regulated. To this end, it reached an agreement in early 1995 with the country's largest cable group - Promotora de Informaciones SA (Prisa) - whereby the operator provided the cable TV infrastructure and Prisa the content (Político, 17 July 1996). On that front, and by an initial formula for entry, it formed a partnership with Canal + to set up a cable television company called Cablevisión in July 1992, which remained inactive in the absence of an appropriate legal framework. In July 1995 Canal Plus and Sogecable S. A. carried out a concentration consisting of the acquisition of joint control of Cablevisión. The entry of a large number of companies of varying sizes, as well as public entities, into the cable market despite this legal vacuum led the shareholders of Cablevisión to reactivate the company. In a precedent-setting agreement between Telefónica and Canal Plus, by a decision of 9 November 1994, the European Commission vetoed the creation of Media-Service, MSG, a joint venture between the dominant telephone operator in Germany, Deutsche Telekom, Bertelsmann and a major multimedia group, because of the concentration involved and the detrimental effect on equality of opportunity. The decision to suspend MSG was made on the basis of the Basic Treaty of the European Community: Commission Decision of 9 November 1994 relating to a proceeding pursuant to Council Regulation (EEC) No 4064/89 (IV/M.469-MSG Media Service), 94/922/EC. The agreement on MSG was extremely similar to, and even shorter than, that made by Telefónica and Canal Plus. Barcelona City Council has signed an agreement with US West, one of the telephone operators in the United States and the largest shareholder in the Time Warner group, to cable the Catalan capital (El País, 30 July 1995).

From this cornerstone, they created a series of companies that shared the same approach, partners, share capital and even the basic name. All of them had a local or regional scope and in all cases Telefónica participated with $51 \%$ of the share capital, which was always valued at 100 million pesetas. We are talking about two companies in Catalan-speaking territory - Societat General de Cablevisió Balears and Societat General de Cablevisió Lleida, one in the Basque Country - Sociedad General de Cablevisión Bizkaia-, one in Navarre - Sociedad General de Cablevisión Navarra-, one 
in Murcia - Sociedad General de Cablevisión Murcia- and two in Andalusia - Sociedad General de Cablevisión Sevilla and Sociedad General de Cablevisión Cádiz. Under a second entry formula, Telefónica acquired $29 \%$ of the capital in Sociedad General de Cablevisión Madrid and Cablevisión Barcelona from Sociedad General de Cablevisión (LACA, 20 December 1995).

The development of cable television was not without conflict. We have evidence of this in the Small Claims Trial for Unfair Competition against Telefónica and Sociedad General Cablevisión brought by Cableuropa S. A. and the Order of the Court of First Instance No 55 of Madrid, which granted the interim measures requested by Cableuropa, while Telefónica's request for clarification was rejected (LACA, 26 June 1996). The reply extended to the concessions, as was the case with the concession granted to Huelva de Cable y Television for the provision of the public cable telecommunications service in the territorial demarcation of Huelva. The Contracting Committee fully accepted the technical and economic criteria of the technical report drawn up by the Technical Services of the Ministry of Development, which stated that the two evaluated bids met the minimum technical requirements established and that the partial scores obtained by the bids submitted. The offer presented by Huelva de Cable y Televisión obtained a higher score (Congress of Deputies, BOCG, D-314, 13 August 1998, p. 233). Without doubt, the fiercest battle for cable was caused by the government's concession to the PRISA group, which was denounced by the competition - Antena $3 \mathrm{TV}$ - and the opposition press as being detrimental to the free competition - collusion and abuse of a dominant position - and to the very development of the cable and information highway industry in Spain and representing the handing over to Canal + of exclusive rights to cable television programming without compensation, the marketing of all the content that would circulate on Telefónica's information highways and the use of the Canal + decoder, which is also considered a technologically obsolete product (El Mundo, 29 July 1995). The strategic agreement between Canal Plus and Telefónica for the development of cable television led to the creation of Cablevisión in July 1992. Canal Plus justified the new company in a notification from the Ministry of Transport, Public Works and the Environment to Telefónica that it could start operating under the cover of a ruling by the Constitutional Court (Release of Canal Plus, 27 July 1995). The Government supported the decision of Compañía Telefónica de España, S. A., to start cable television broadcasting through its subsidiary Cablevisión before the approval of the corresponding bill. The executive justified the decision by the doctrine of the Constitutional Court, which, moreover, limited cable activity to the local level. Appearance by the Minister of Public Works, Transport and the Environment (Journal of Sessions, Congress of Deputies, Commissions, 558, 20 September 1995, p. 16.974). On 8 February 1996, the European Commission notified the Spanish Competition Court, Telefónica and Canal Plus that the agreement of both companies distorted free competition in Spain (Annexe 2). The Commission described the creation of Cablevisión as an operation with a Community dimension, which also raised serious doubts as to its compatibility with the common 
market. It also launched an in-depth investigation into the effects of the creation of Cablevisión, before taking a final decision on the authorization, prohibition or licensing under conditions of Cablevisión: European Commission, Press Release, 22 July 1996. Telefónica's alliance with Canal Plus in respect of Cablevisión: the President of Telefónica requested the rapid resolution of the case: LACA, 24 July 1996. On the disputes in the sector (Pérez Gómez, 2011).

Three rulings in the proceedings initiated by complaints from three local cable television companies - Burgos Sistemas de Cable, Santander Sistemas de Cable and Jerez Sistemas de Cable - were in favour of preventing Telefónica from providing services with its infrastructure. The decisions specified Telefónica's obligation to establish the necessary infrastructure to support the various services. Besides, the National Telecommunications Plan provided for the implementation of broadband ISDN from the basic network. In Telefónica's opinion, preventing it from providing services was contrary to the principle of optimising this network and to the doctrine of the Constitutional Court, which favours the freedom to offer local cable television services, and to one of the clauses of the contract with the State (LACA, 29 November 1995).

\section{Conclusion.}

This article has analysed the opening up telecommunications to competition and its factors in Spain, a country very committed to the monopoly, in the general context of an accelerated technological change, a sharp regulatory change and an extension of the value chain with new products and services, in particular data, mobile telephony and cable. The study, interdisciplinary in nature and backed on primary sources, has focused on Telefónica's response to new regulatory and market requirements.

The evidence presented leads to the conclusion that the extension of the value chain ran in parallel with successive reorganisations of Telefónica to respond to market demands. Furthermore, the availability of infrastructure has allowed the former monopoly to launch itself on the market before it was regulated, while the absence of regulation has hampered the emergence of new initiatives.

The evidence also reveals a widening of the financial base of new companies that clearly go beyond the traditional field of telecommunications.

\section{Annexe 1. Consortia established to operate in cable television (1995)} (Comisión del Mercado de las Telecomunicaciones; Giordano and Zeller, 1999, p. 216).

Cableuropa: BCH, BBV, Banco de Santander, Corporación Industrial Banesto, IBV (Iberdrola BBV) and Multitel Cable (Lince Telecomunicaciones).

Cablevisión: Telefónica, Telecartera, Prisa and Sogecable.

Sevillana de Cable: BCH, BBV, Banco de Santander, Banesto, CAT, Nuintel, Multitel, Sevillana de Electricidad, Sodian and Instituto de Fomento de Andalucía. 
Jerez de Cable: Sevillana de Cable, Multitel, Joly de Comunicaciones, CSM (Israeli investor group of communication), Banco Santander, El Corte Inglés, Corporación Municipal Jerez, Taridan and Diario de Cádiz.

Santander de Cable: Electra del Viesgo, Caja Cantabria, Editorial Cantabria, UIH, Ayuntamiento de Santander, Banco Santander and Diario Montañés.

Telecable Compostela: El Correo Gallego, Intelsis and Daviña.

Burgos Sistema de Cable: Caja Círculo Católico, Ical Cable, Diario de Burgos, UIH and Multitel.

Cable del Guadalquivir: Telefónica, servicios multimedia, Abengoa, Grupo ZAntena 3 televisión, El Monte, Trébol internacional, AF División Imagen and Medios de comunicación sevillanos.

Cable TV Europa: Multimedia Cable, (Catalana d'Iniciatives), Time Warner-US West and TCI.

Grupo Cable: Banco Pastor, Caja de Pontevedra, Caja de Vigo, Caja de Orense, Caja Galicia, Grupo Z, Antena 3-TV, Voz de Galicia, Telefónica, Unión Fenosa and Televés-Intelsis.

Operadora Cable Sistema: Telefónica, Caja Cataluña, Cirsa Group and Antena 3TV.

Zaragoza de Cable: Bell Canada, Jones Intercable, Mercury, Multitel, Ibertele, Tecnodeasa and Multimedia.

Marbella Cablevisión: Milisat, Int. Network TV and Ayuntamiento de Marbella.

\section{Annexe 2. Disputes arising from the agreement between Telefónica and Canal Plus.}

The Court of Competition examined the notification of the concentration submitted in October 1995 by Telefónica, Canal Plus and Sogecable S.A. and submitted a proposal to the Minister for Economic Affairs and Finance to order that the file be referred to the Court for its opinion, on the ground that it might impede the maintenance of effective competition in the Spanish cable telecommunications market. In December 1995, Jerez de Cable SA and Santander de Cable SA denounced Telefónica and Canal Plus for having entered into the abovementioned strategic agreement restricting competition and, moreover, Telefónica for abuse of a dominant position, because they considered that the provision of local cable television services infringed the contract which it had concluded with the State in 1991. The Court found for the most part that the notified operation constituted a strategic alliance of a cooperative nature without the character of an economic concentration from the point of view of national competition law. On the other hand, the European Commission did see an economic concentration with a Community dimension but took the view that the strategic agreement signed between Telefónica and Sogecable/Canal Plus could be separated from the concentration relating to Cablevisión and analysed at the time from the point of view of Articles 85 and 86 of the Treaty on European Union. In view of this situation, and after analysing three possibilities, the Court decided to submit a 
report to the Minister of Economy and Finance for referral to the Government, setting out up to five conclusions, the last of which was of a recommendatory nature. To begin with, the Court denied that the operation was an economic concentration from the perspective of the LDC. It also released the Government from the obligation to rule on the operation until a formal decision of the European Commission on the Community or national dimension of the operation was taken. Thirdly, if the Commission refused to intervene because the concentration did not have a Community dimension, the Court considered that the Government should order the opening of disciplinary proceedings in respect of those facts. Fourthly, the Court considered that the operation could not and should not be authorized because the notified agreements would have various adverse effects on free competition in various fields. They would prevent the emergence in Spain of a competitor to Telefónica in the cable business, close the market to potential competitors of Eurodec in the decoders sector, Cablevisión in the supply of services to cable operators and Canal Plus in the programming field. The end result would be reduced consumer choice and increased prices (Merger Court Report, CNMV, C21/95: CABLEVISION, 14 March 1996).

\section{Acknowledgements.}

This study is assigned to the Centre d'Estudis 'Antoni de Capmany' d'Economia i Història Econòmica, Department of Economic History, Institutions and Policy and World Economy, Faculty of Economics and Business (Universitat de Barcelona, Spain). I would like to thank those responsible for supporting my research as well as the editors of this Journal.

\section{References}

Adizes, I. (2004). Managing corporate lifecycles. Santa Bárbara CA: The adizes institute publishing.

Binda, V. (2013). The dynamics of big business: structure, strategy, and impact in Italy and Spain. London: Routledge.

Boletín Oficial del Estado.

Calvo, A. (2016). Historia de telefónica: 1976-2000. Las telecomunicaciones en la España democrática. Barcelona: Ariel [in Spanish].

Chandler, A. (1990). Scale and scope. Cambridge, MA: Cambridge University Press.

Donaldson, G. (1994). Corporate restructuring: Managing the change process from within. Boston, MA: Harvard Business Press.

Eijk, N. A. N. M. (1995). Cable Television Networks in Europe. Retrieved from https://www.ivir.nl/publicaties/download/eurcable.pdf

Compañía Telefónica Nacional de España, Memoria [in Spanish].

Dul, J., \& Hak, T. (2008). Methodology in business research. Amsterdam, Boston, Heilderberg: Blutterworth-Heinemann.

El Mundo [in Spanish]. 
El Pais [in Spanish].

European Audiovisual Observatory. (2004). Regulating Access to Digital Television.

Strasbourg: European Audiovisual Observatory.

Fernández, R. V. (2000). La televisión por cable en España. Análisis y formulación de estrategias para los nuevos operadores (Doctoral dissertation, Universidad de Málaga) [in Spanish].

Frèches, J. (1987). La Télévision par câble. Paris: PUF [in French].

From, J., \& Eliassen, K. A. (2007). The Privatisation of European Telecommunications. Hampshire: Ashgate.

General Accounting Office (2003). Telecommunications issues related to competition and subscriber rates in the cable television industry. Darby, PA: DIANE Publishing.

Giordano, E., \& Zeller, C. (1999). Políticas de televisión: la configuración del mercado. Barcelona: Icaria Editorial [in Spanish].

Hollensen, S. (2012). Global marketing: a decision-oriented approach. Upper Saddle River, NJ: Financial Times Prentice Hall.

Hugues, Th. P. (1983). Networks of Power. Electrification in Western Society, 1880 1930. Boulder, CO: Westview Press.

Jakopin, N. M. (2008). Internationalisation in the telecommunications services industry: literature review and research agenda. Telecommunications Policy, 32(8), 531-544. https://doi.org/10.1016/j.telpol.2008.06.003

Journal of Sessions, Congress of Deputies, Commissions.

Kalotay, K. (2004). The rise of foreign direct investment in the telecommunications services of developing countries. The Journal of World Investment \& Trade, 5(5), 811-832. https://doi.org/10.1163/221190004X00056

Kranzberg, M. (1986). Technology and history: 'Kranzberg's Laws'. Technology and Culture, 27(3), 544-560. https://doi.org/10.1177\%2F027046769501500104

Lange, A. (2005). The financial situation of television companies in the European Union (1999-2004). Strasbourg: Council of Europe.

Leontiades, J. C. (1987). Multinational corporate strategy: planning for world markets. New York: Lexington Books.

Libros de Actas del Consejo de Administración, LACA.

Little, A. D. (1997). Cable review, report to the european commission (DG IV), July. Retrieved from http://aei.pitt.edu/id/eprint/41149

Magoun, A. B. (2007). Television: the life story of a technology. Westport, CT: Greenwood Publishing Group.

Martí-Recober, M. (1991). Llibre blanc sobre les telecomunicacions a Catalunya. Barcelona: Generalitat de Catalunya and Telefónica [in Catalan].

Mayntz, R., \& Hughes, T. P. (1988). The development of large technical systems. Frankfurt \& Boulder: Westview and Campus.

Merger Court Report, CNMV, C21/95: CABLEVISION, 14 March 1996. 
Miguel, J. C., \& Fernández Peña, E. (1998). Las alianzas en el inicio del mercado del cable en España: un enfoque institucional. Revista de estudios de comunicación, 3(4), 1-10 [in Spanish].

Montes, F. J. (2016). Historia de la televisión por cable en España. 1994 -1996 (II). Anuario Jurídico y Económico Escurialense, XLIX, 549-578 [in Spanish].

Mullen, M. (2008). Television in the multichannel age: a brief history of cable television. Malden, MA: Wiley-Blackwell.

New York Times, December 19, 1971, p. 10.

OECD (2000). Reviews of Regulatory Reform: Regulatory Reform in Spain 2000. Paris: COIT.

Pérez Martínez, J., \& Feijóo González, C. (2000). Convergencia, competencia y regulación en los mercados de las telecomunicaciones, el audiovisual e Internet. Madrid, Editorial GRETEL, 83 [in Spanish].

Pérez-Gómez, M. Á. (2011). Previously On. Estudios interdisciplinarios sobre la ficción televisiva en la Tercera Edad de Oro de la Televisión [in Spanish].

Rosenberg, N. (1982). Inside the black box: technology and economics. Cambridge: Cambridge University Press.

Secretaría General de Economía y Planificación. (1985). Programa económico a medio plazo. Vol. 5. Madrid: Ministerio de Economía y Hacienda [in Spanish].

Sloan Commission on Cable Communications. (1971). On the cable: the television of abundance: report. New York: McGraw-Hill Book Co.

Spain, P. J., \& Talbot, J. R. (Eds.). (1995). Hoover's Handbook of American Companies 1996. Austin, TX: Hoovers Incorporated.

Svedberg, B. (1981). Ericsson Towards the 1990s.

Telefónica, Memoria.

Wheeler, Th. E. (1981). Statement, rural telecommunications: hearing before the subcommittee on communications of the committee on commerce, science, and transportation. United States Senate, Ninety-seventh Congress, June 22. Washington: U.S. Government Printing Office.

Whittington, R., \& Mayer, M. (2000). The European corporation: strategy, structure, and social science. Oxford: Oxford University Press on Demand.

Wormbs, N. (1997). Through thread and ether. The emergence of the distribution network for radio and television [in Swedish]. Stockholm: Norstedt.

\section{Анхель Кальво}

Університет Барселони, Барселона, Іспанія

\section{Лібералізація телекомунікацій і розширення ланцюжка доданої вартості в Південній Європі. Telefónica, 1982-2000 роки}

Анотація. Ця стаття розглядає історію конкуренщії телекомунікаційних систем в Іспанї (країні, яка має серйозні монополістичні тенденщіï) і фактори, 
щуо визначають изю конкурениію. Стаття аналізує загальний сценарій прискорення технологічних змін, викликаних новими матеріалами, компонентами $i$ системами передачі, різкими змінами в законодавстві $i$ розширенням ланцююка створення вартості за рахунок нових продуктів $i$ послуг, зокрема баз даних, мобільного телефонного зв'язку і кабелю. Зазначені вище властивості ідеально вписуються в обрану тимчасову вісь, яка охоплює два останніх десятиліття 20-го століття $і$ збігається з етапом, на якому конкуруючі компанї зіткнулися з проблемою не тільки лібералізації, але й глибоких змін параметрів ринку. Основна увага в дослідженні приділяється розгляду відповідних кроків компанії Telefónica на нові нормативні та ринкові вимоги. Методологічно дослідження має мультидисииплінарний характер, який об'єднує підходи історії техніки, щуо розуміється як система (Томас П. Хьюз $i$ Мелвін Кранцберг), і історії економіки та бізнесу (Натан Розенберг). Текст складається з чотирьох розділів, в яких досліджується збереження монополії Telefonica $і$ лібералізачія, осі трансформаціï Telefónica через глобальні та стратегічні плани і розширення ланцюжка створення доданої вартості 3 упором на кабельний ринок. Розглянуто деякі попередні історичні та технічні питання та ключові елементи еволючії сектора. У статті розглядаються відносини між ринковою структурою, успадкованої від монополії, $і$ прочесом, $з$ якого виникають переваги компанї Telefóniса в порівнянні з іншими компаніями. Дослідження грунтується в основному на первинних джерелах вивченої компанії, які вдвічі изініші, бо вони важкодоступні для дослідників $і$ повністю ілюстративний для розуміння стратегї компанії, а також на звітах великих міжнародних організачій та вторинної літературі. Автор приходить до висновку про наявність тісного зв'язку між факторами попиту і пропозицї.

Ключові слова: лібералізація телекомунікацій; Telefónica; кабельне телебачення; ланцңюжок значень

\section{Анхель Кальво}

Университет Барселоны, Барселона, Испания

\section{Либерализация телекоммуникаций и расширение цепочки добавленной стоимости в Южной Европе. Telefónica, 1982-2000 годы}

Аннотация. Эта статья рассматривает историю конкуренциии телекоммуникационных систем в Испании (стране, которая имеет серьезные монополистические тенденциии) и факторы, определяющче эту конкуренцию. Статья анализирует общий сценарий ускорения технологических изменений, вызванных новыми материалами, компонентами и системами передачи, резкими изменениями в законодательстве и расширением цзепочки создания стоимости за счет новых продуктов и услуг, в частности данных, мобильной телефонной связи и кабеля. Указанные выне свойства идеально вписываются в 
выгранную временную ось, которая охватывает два последних десятилетия 20 го века и совпадает с этапом, на котором конкурирующче компании столкнулись с проблемой не только либерализации, но и глубокого изменения параметров рынка. Основное внимание в исследовании уделяется рассмотрению ответных шагов компании Telefónіса на новые нормативные и рыночные требования. Методологически исследование имеет мультидисииплинарнылй характер, который объединяет подходы истории техники, понимаемой как система (Томас П. Хьюз и Мелвин Кранцберг), и истории экономики и бизнеса (Натан Розенберг). Текст состоит из четырех разделов, в которых исследуется сохранение монополии Telefonica и либерализация, оси трансформации Telefónica через глобальные и стратегчческие планы и расширение иепочки создания добавленной стоимости с упором на кабельный рынок. Рассмотрены некоторые предварительные исторические и технические вопросы и ключевые элементы эволющии сектора. В статье рассматриваются отношения между рыночной структурой, унаследованной от монополии, и прочессом, из которого проистекают преимущества компании Telefónica по сравнению с остальными компаниями. Исследование основывается в основном на первичных источниках изученной компании, которые вдвое более ценны, потому что они труднодоступнь для исследователей и полностью иллюстративнь для понимания стратегии компании, а также на отчетах крупных международных организаций и вторичной литературе. Автор приходит к выводу о наличии тесной связи между факторами спроса и предложения.

Ключевые слова: либерализачия телекоммуникаций; Telefónica; кабельное телевидение; цуепочка значений

Received 18.10.2020

Received in revised form 23.11.2020

Accepted 28.11.2020 